\title{
PENGARUH KARAKTERISTIK PERUSAHAAN DAN AUDITOR TERHADAP AUDIT DELAY (Studi Kasus Pada Perusahaan Hotel, Restoran, dan Pariwisata di Bursa Efek Indonesia)
}

\author{
Citra Dirgahayu Innayati dan Endah Susilowati \\ Program Studi Akuntansi-Fakultas Ekonomi dan Bisnis UPN Veteran Jawa Tjmur, \\ Email: citradirgahayu17@gmail.com,dan endah.susilowati64@yahoo.co.id
}

\begin{abstract}
This study aimed to test, to prove and analyze the influence of company size, complexity of operations of the Company, Reputation of Audit Firm and Auditor's Opinion toward audit delay. Variabel this research is company size, complexity of operations of the Company, Reputation of Audit Firm, Auditor's Opinion, and Audit Delay. The sample was company Hotel, Restaurant, and Tourism, which is listed on the Stock Exchange 2010- 2013. The sample selection using purposive sampling and obtained 40 samples of 10 companies during 2010-2013. The data used in this research are secondary data from the annual financial statements (Annual Report) sector company Hotel Restaurant, and Tourism, which is listed on the Indonesia Stock Exchange 2010-2013, audited and then classified based on the criteria that have been determined. Techniques of analysis using multiple linear regression analysis with dummy variables. Based on the research that has been done to prove that the resulting regression model is not appropriate to examine the influence of company size, complexity of operations of the Company, Reputation of Audit Firm and Auditor's Opinion toward Audit Delay. Based on the partial testing proves that the company size, complexity of operations of the Company, Reputation of Audit Firm and Auditor's Opinion no significant effect on audit delay.
\end{abstract}

Keywords: company size, complexity of operations of the Company, Reputation of Audit Firm, Auditor's Opinion, and Audit delay

Abstrak: Penelitian ini bertujuan untuk menguji, membuktikan, dan menganalisis pengaruh Ukuran Perusahaan, Kompleksitas Operasi Perusahaan, Reputasi KAP, dan Opini Auditor terhadap Audit delay.Variabel penelitian ini adalah Ukuran Perusahaan, Kompleksitas Operasi Perusahaan, Reputasi KAP, Opini Auditor, dan Audit Delay. Sampel penelitian ini adalah perusahaan Hotel, Restoran, dan Pariwisata yang terdaftar di BEI periode 2010-2013. Pemilihan sampel menggunakan purposive sampling dan diperoleh 40 sampel dari 10 perusahaan selama tahun 2010-2013. Data yang digunakan dalam penelitian ini adalah data sekunder berupa laporan keuangan tahunan (Annual Report) perusahaan sektor Hotel Restoran, dan Pariwisata yang terdaftar di Bursa Efek Indonesia periode 2010-2013 yang telah diaudit dan kemudian diklasifikasikan berdasarkan kriteria-kriteria yang telah ditentukan. Teknik analisis menggunakan analisis regresi linier berganda dengan variabel dummy. Berdasarkan hasil penelitian yang telah dilakukan membuktikan bahwa model regresi yang dihasilkan tidak sesuai untuk menguji pengaruh Ukuran Perusahaan, Kompleksitas Operasi Perusahaan, Reputasi KAP, dan Opini Auditor terhadap Audit Delay. Berdasarkan pengujian parsial 
membuktikan bahwa Ukuran Perusahaan, Kompleksitas Operasi Perusahaan, Reputasi KAP, dan Opini Auditor tidak berpengaruh signifikan terhadap audit delay.

Kata Kunci: Ukuran Perusahaan, Kompleksitas Operasi Perusahaan, Reputasi KAP, Opini Auditor, dan Audit delay

\section{PENDAHULUAN}

Laporan keuangan memberikan informasi yang akan dibutuhkan oleh Investor dan pengguna laporan keuangan lainnya untuk digunakan dalam pengambilan keputusan. Informasi yang disajikan dalam laporan keuangan seharusnya dapat memberikan informasi yang akurat, tepat waktu, dan dapat dibandingkan agar Investor dapat menentukan dengan cepat langkah yang harus dilakukan dalam hal kegiatan Investasi. Perusahaan akan selalu berusaha agar laporan keuangannya berada pada kondisi yang baik, sehingga dengan adanya hal tersebut, maka diperlukan pihak yang dapat melakukan pemeriksaan terhadap nilai yang terkandung dalam laporan keuangan perusahaan agar terbebas dari salah saji material. Pihak yang bertugas dalam melakukan pemeriksaan laporan keuangan perusahaan yaitu Auditor Independen. Selisih antara tanggal laporan keuangan dengan tanggal opini audit disebut dengan Audit delay (Saputri, 2012). Audit delay dapat berdampak negatif pada reaksi pasar (Widyasari, 2011), hal ini terjadi karena Investor menganggap keterlambatan pelaporan keuangan merupakan pertanda buruk bagi kondisi kesehatan perusahaan. Perkembangan sektor pariwisata menempati urutan kelima sebagai penyumbang devisa negara tahun 2012, hal ini dapat dilihat dari jumlah Wisatawan Mancanegara yang berkunjung ke Indonesia sebanyak 8,04 juta Wisman (Putra, 2013). Dan diperkirakan pada tahun 2013 akan mengalami peningkatan sebesar 7,3 persen dibandingkan tahun 2012. Pertumbuhan pariwisata ini akan berdampak pada pertumbuhan industri pendukungnya seperti Hotel, dan Restoran (Gambar 1).

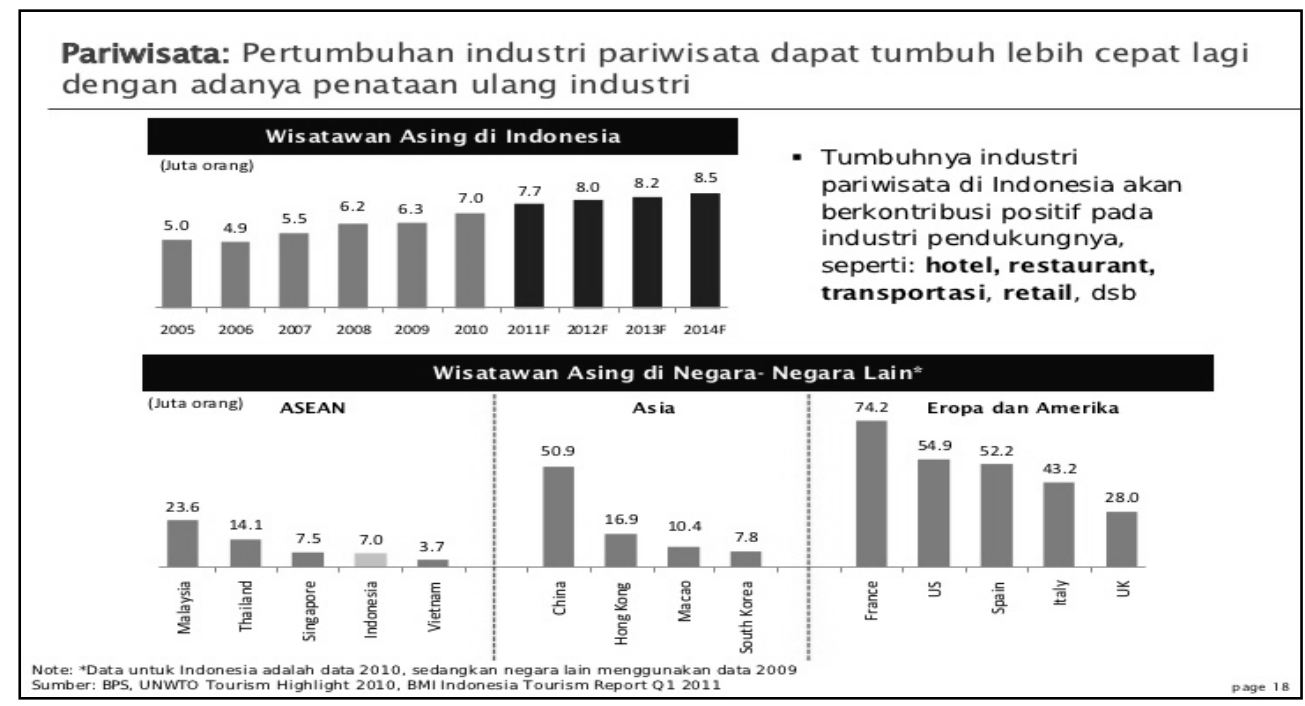

Gambar 1: Pertumbuhan Industri Pariwisata

Sumber: Erwin, 2012, "Prospek dan Tantangan Ekonomi Indonesia, http://www.slide share.net?ErwinEananto/prospek-dan-tantanganekonomi-indonesia, diakses tanggal 28 Januari 2015, 23.53 
Perkembangan Perusahaan sektor Hotel, Restoran, dan Pariwisata ternyata tidak diikuti dengan kepatuhan perusahaan akan penyampaian laporan keuangan auditan di Bursa Efek Indonesia (Tabel 1).

Tabel 1. Rata-Rata Audit Delay Perusahaan Sektor Hotel, Restoran, dan Pariwisata Tahun 2010-2013

\begin{tabular}{ccc}
\hline Tahun & Jumlah Perusahaan & Rata-Rata Audit Delay \\
\hline 2010 & 18 & 89 hari \\
2011 & 17 & 88 hari \\
2012 & 17 & 79 hari \\
2013 & 17 & 89 hari
\end{tabular}

Sumber: Bursa Efek Indonesia, 2015, “Laporan Keuangan”, http://www.idx.co.id/id-

Id/beranda/perusahaantercatat/laporankeuangandantahunan.aspx, diakses tanggal 3 Maret 2015, 19.37, data diolah

Beberapa penelitian mengenai audit delay pernah dilakukan sebelumnya namun masih terdapat perbedaan. Hasil penelitian Kartika (2011) membuktikan bahwa ukuran perusahaan, dan solvabilitas berpengaruh signifikan terhadap audit delay. Operasi kerugian dan keuntungan, profitabilitas, opini auditor, dan reputasi auditor tidak memiliki pengaruh terhadap audit delay. Prameswari (2012) membuktikan bahwa Solvabilitas dan Perusahaan Holding berpengaruh terhadap audit delay, sedangkan Opini Auditor, profitabilitas, dan lamanya perusahaan menjadi klien KAP tidak berpengaruh terhadap audit delay. Ramadhan (2012) membuktikan bahwa likuiditas, rasio aktivitas, ukuran perusahaan dan kualitas Kantor Akuntan Publik tidak berpengaruh secara signifikan terhadap audit delay, sedangkan profitabilitas berpengaruh negatif terhadap Audit delay. Puspitasari, dkk., (2012) membuktikan bahwa ukuran perusahaan, solvabilitas, laba/ rugi perusahaan, dan ukuran KAP berpengaruh secara signifikan terhadap audit delay. Saputri (2012) membuktikan bahwa laba atau rugi, opini auditor, reputasi KAP dan kompleksitas operasi perusahaan berpengaruh terhadap audit delay, sedangkan ukuran perusahaan dan jenis industri tidak berpengaruh terhadap audit delay.Kusumawardani (2013) membuktikan bahwa kondisi perusahaan, ukuran kantor akuntan publik, dan opini auditor berpengaruh terhadap audit delay. Angruningrum, dkk (2013) membuktikan bahwa hanya variabel leverage yang berpengaruh terhadap Audit delay, sedangkan variabel profitabilitas, kompleksitas operasi perusahaan, reputasi KAP, dan komite audit tidak mempengaruhi Audit delay.

Berdasarkan fenomena di atas, maka faktor yang diuji kembali dalam penelitian ini adalah Ukuran Perusahaan, Kompleksitas Operasi Perusahaan, Reputasi KAP, dan Opini Auditor sebagai variabel Independen dan Audit Delay sebagai variabel Dependen. Perumusan masalah apakah Ukuran Perusahaan, Kompleksitas Operasi Perusahaan, Reputasi KAP, dan Opini Auditor berpengaruh terhadap Audit delay. Tujuan penelitian ini untuk menguji, membuktikan, dan menganalisis pengaruh Ukuran Perusahaan, Kompleksitas Operasi Perusahaan, Reputasi KAP, dan Opini Auditor terhadap Audit delay. 


\section{KAJIAN TEORI}

Audit delay. Audit delay merupakan lamanya atau rentang waktu penyelesaian audit yang diukur dari tanggal penutupan tahun buku sampai dengan tanggal diterbitkannya laporan audit (Kartika, 2011). Rentang waktu tersebut menyebabkan keterlambatan dalam penyampaian laporan keuangan ke Bursa Efek Indonesia (BEI). Jika perusahaan menyampaikan laporan keuangan melebihi batas penyampaian laporan keuangan yang telah ditetapkan BAPEPAM-LK, maka perusahaan dikatakan terlambat. Keterlambatan tersebut akan menimbulkan reaksi negatif bagi Investor sehingga akan menyebabkan pengambilan keputusan menjadi tertunda.

Ukuran perusahaan. Ukuran perusahaan mengindikasikan bahwa perusahaan tersebut digolongkan sebagai perusahaan kecil atau perusahaan besar. Besar kecilnya suatu perusahaan ditijau dari sudut kepemilikan modal dan aset perusahaan. Penelitian Febriyanti (2011) mengelompokkan Ukuran Perusahaan menjadi tiga kategori, yaitu perusahaan besar (large firm), perusahaan menengah (medium size), dan perusahaan kecil (small firm). Kategori Ukuran Perusahaan yaitu Perusahaan Besar dengan kekayaan bersih lebih besar dari Rp10 Milyar termasuk tanah, dan bangunan. Memiliki penjualan lebih dari Rp50 Milyar/ tahun, Perusahaan Menengah dengan kekayaan bersih Rp1-10 Milyar termasuk tanah, dan bangunan. Memiliki hasil penjualan lebih besar dari Rp1 Milyar dan kurang dari Rp50 Milyar/ tahun, dan Perusahaan Kecil dengan kekayaan bersih paling banyak Rp200 juta tidak termasuk tanah, dan bangunan dan memiliki hasil penjualan minimal Rp1 Milyar/ tahun.

Kompleksitas Operasi Perusahaan. Kompleksitas operasi perusahaan berhubungan dengan unit-unit perusahaan yang saling bekerjasama dan saling mempengaruhi untuk mencapai tujuan perusahaan. Kompleksitas yang ada dalam perusahaan diukur dari banyaknya jumlah anak perusahaan yang dimiliki oleh perusahaan induk. Jumlah anak perusahaan suatu perusahaan mewakili kompleksitas jasa audit yang diberikan yang merupakan ukuran rumit atau tidaknya transaksi yanng dimiliki oleh klien KAP untuk diaudit (Widosari, 2012).

Reputasi KAP. KAP yang memiliki reputasi yang baik digolongkan pada KAP yang termasuk dalam kateori KAP big four, di mana KAP big four adalah organisasi internasional besar yang memiliki pendapatan tahunan global berkisar antara \$10 miliar sampai \$14 miliar dan telah mengaudit sekitar 80\% dari seluruh perusahaan publik di Amerika Serikat dan lebih dari 90\% perusahaan publik dengan penjualan tahunan lebih besar dari \$1 juta (Glover, dkk., 2005: 59). Dalam penelitian Pratama (2014), Keempat KAP besar yang berafilisasi dengan KAP di Indonesia, yaitu: (1) KAP Price Waterhouse Coopers, yang bekerja sama dengan KAP Tanudiredja, Wibisana \&Rekan; (2) KAP KPMG ( Klynveld Peat Marwick Goerdeler), yang bekerja sama dengan KAP Siddharta danWidjaja; (3) KAP Ernst \& Young, yang bekerja sama dengan KAP Purwantono,Suherman dan Surja; (4) KAP Deloitte Touche Tohmatsu , yang bekerja sama dengan KAP Osman Bing Satrio. 
Opini Auditor. Opini Auditor merupakan tanggung jawab akuntan publik untuk membuktikan tentang kondisi keuangan perusahaan. Dalam penyelesaian proses audit maka Auditor akan memberikan opini mengenai kondisi keuangan perusahaan yang dicantumkan dalam laporan Auditor independen. Menurut Agoes (2012: 75) Opini Auditor menurut SAK yaitu terdiri dari 5 jenis opini yaitu: (1) Pendapat wajar tanpa pengecualian; (2) Pendapat wajar tanpa pengecualian dengan bahasa penjelasan; (3) Pendapat wajar dengan pengecualian; (4) Pendapat tidak wajar; (5) Penyataan tidak memberikan pendapat.

Pengaruh Ukuran Perusahaan terhadap Audit delay. Ukuran perusahaan dapat ditentukan melalui total aset yang dimiliki perusahaan, semakin besar total aset perusahaan maka semakin besar pula ukuran suatu perusahaan. Hasil penelitian Puspitasari, dkk., (2012), dan Ardiansah (2011), membuktikan bahwa ukuran perusahaan berpengaruh positif terhadap audit delay, yang artinya semakin besar total aset yang dimiliki oleh suatu perusahaan, maka semakin besar audit delay, perusahaan yang mempunyai total aset yang lebih besar akan menyelesaikan audit lebih lama dibandingkan dengan perusahaan yang mempunyai total aset lebih kecil, dikarenakan jumlah sampel yang harus diambil semakin besar dan semakin banyak prosedur audit yang harus ditempuh. Berdasarkan uraian di atas maka hipotesis disusun sebagai berikut:

$\mathrm{H}_{1}$ : Ukuran Perusahaan berpengaruh signifikan terhadap Audit delay.

Pengaruh Kompleksitas Operasi Perusahaan Terhadap Audit delay. Kompleksitas Operasi Perusahaan berhubungan dengan kerumitan yang ada dalam perusahaan dikarenakan jumlah anak perusahaan yang dimiliki oleh perusahaan induk. Hasil penelitian Saputri (2012) dan Ariyani (2014), membuktikan bahwa Kompleksitas Operasi Perusahaan berpengaruh positif terhadap audit delay, yang artinya semakin tinggi kompleksitas operasi suatu perusahaan, maka semakin panjang audit delay. Hal ini dikarenakan perusahaan yang memiliki unit operasi (cabang) lebih banyak memerlukan waktu yang lebih lama bagi Auditor untuk melakukan pekerjaan auditnya. Apabila perusahaan memiliki anak cabang perusahaan, maka transaksi yang dimiliki klien semakin rumit karena terdapat laporan konsolidasi yang perlu di audit oleh Auditor sehingga akan memerlukan waktu yang cukup lama bagi Auditor untuk melakukan pekerjaan auditnya. Berdasarkan uraian di atas maka hipotesis disusun sebagai berikut:

$\mathrm{H}_{2}$ : Kompleksitas Operasi Perusahaan berpengaruh signifikan terhadapAudit delay

Pengaruh Reputasi KAP Terhadap Audit delay. Jasa KAP berperan penting dalam memeriksa laporan keuangan perusahaan, peran penting tersebut bergantung pada reputasi yang dimiliki KAP tersebut. KAP yang memiliki reputasi yang baik akan lebih bertanggung jawab serta lebih profesional dalam melakukan audit. Hasil penelitian Setiawan (2013) dan Yuliyanti (2011) membuktikan bahwa Reputasi KAP berpengaruh positif terhadap audit delay, yang artinya perusahaan yang diaudit oleh KAP big four akan mengalami peningkatan audit delay. Hal ini bisa terjadi terkait dengan prediksi perusahaan bahwa laporan keuangan perusahaan akan sedikit sulit, sehingga membutuhkan orangorang yang lebih professional untuk menyelesaikan laporan keuangannya. Namun, untuk menyelesaikan laporan keuangan yang baik dengan masalah yang lebih kompleks tentu dibutuhkan waktu yang tidak singkat. Berdasarkan uraian di atas maka hipotesis disusun sebagai berikut:

$\mathrm{H}_{3}$ : Reputasi KAP berpengaruh signifikan terhadap Audit delay 
Pengaruh Opini Auditor Terhadap Audit delay. Laporan Auditor Independen mengandung opini Auditor yang menyatakan bahwa laporan keuangan tersebut mendapatkan opini wajar tanpa pengecualian ataupun opini lain yang termasuk dalam kelima jenis opini Auditor sesuai dengan Standar Profesional Akuntan Publik. Hasil penelitian Saputri (2012) membuktikan bahwa Opini Auditor berpengaruh positif terhadap audit delay, yang artinya perusahaan yang mendapat opini wajar tanpa pengecualian akan mengalami peningkatan audit delay. Hal ini dikarenakan proses pemberian opini auditor melibatkan negosiasi dengan klien, konsultasi dengan partner audit yang lebih senior atau staf teknis lainnya dan perluasan lingkup audit. Berdasarkan uraian di atas maka hipotesis disusun sebagai berikut:

$\mathrm{H}_{4}$ : Opini Auditor berpengaruh signifikan terhadap Audit delay

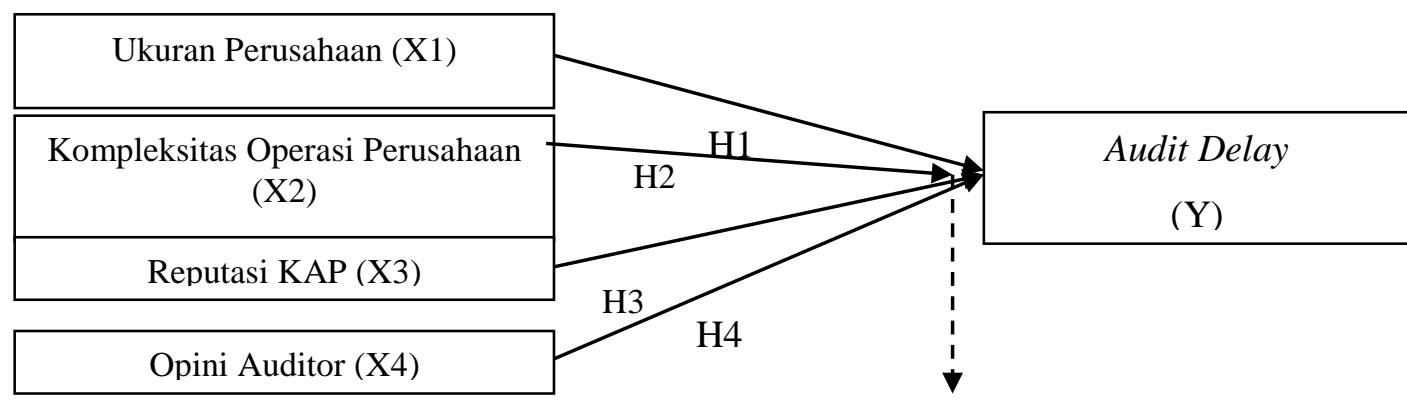

Gambar 2. Rerangka Pemikiran

Analisis regresi Linier Berganda dengan Variabel Dummy

\section{METODE}

Objek penelitian yang digunakan Peneliti adalah Perusahaan Sektor Hotel, Restoran, dan Pariwisata tahun 2010 sampai dengan 2013. Variabel Dependen (Y) dalam penelitian ini yaitu Audit delay yang berarti lamanya atau rentang waktu dalam penyelesaian audit yang diukur dari tanggal laporan keuangan hingga tanggal diterbitkannya laporan audit. Skala pengukuran yang digunakan adalah skala rasio.

\section{Variabel Independen}

1. Ukuran Perusahaan. Ukuran Perusahaan adalah besar kecilnya suatu perusahaan yang diukur berdasarkan total aset. Ukuran Perusahaan dalam penelitian ini diukur dengan menggunakan logaritma total aset dari laporan keuangan tahunan perusahaan. Skala pengukuran yang digunakan adalah skala rasio.

2. Kompleksitas Operasi Perusahaan. Kompleksitas Operasi Perusahaan adalah tingkat kesulitan dalam operasional suatu perusahaan, tingkat kesulitan disini dapat dilihat dari banyaknya jumlah anak perusahaan yang dimiliki oleh perusahaan induk. Kompleksitas Operasi Perusahaan dalam penelitian ini diukur menggunakan jumlah anak perusahaan yang dimiliki oleh perusahaan sampel. Skala pengukuran yang digunakan adalah skala rasio.

3. Reputasi KAP. Reputasi KAP berhubungan dengan profesionalitas yang dimiliki Auditor dalam melaksanakan tugasnya, dalam hal ini berkaitan dengan adanya KAP yang berafiliasi dengan KAP big four. Reputasi KAP dalam penelitian ini diukur 
dengan menggunakan variabel dummy, yaitu yang termasuk dalam KAP big four diberi kode 1 sedangkan KAP non big four diberi kode 0 . Skala pengukuran yang digunakan adalah skala nominal.

4. Opini Auditor. Opini Auditor akan dijadikan pertimbangan oleh Investor dan pengguna laporan keuangan lainnya dalam pengambilan keputusan. Opini Auditor dalam penelitian ini diukur dengan menggunakan variabel dummy, yaitu opini wajar tanpa pengecualian (Unqualified Opinion) dengan kode dummy 1 dan selain wajar tanpa pengecualian dengan kode dummy 0 . Skala pengukuran yang digunakan adalah skala nominal.

Teknik Penentuan Sampel. Populasi dalam penelitian ini adalah perusahaan sektor Hotel, Restoran, dan Pariwisata yang terdaftar di Bursa Efek Indonesia periode 2010-2013 yang berjumlah 19 Perusahaan. Teknik pengambilan sampel yang digunakan penulis menggunakan teknik pengambilan sampel secara tidak acak (Non Random Sampling), berdasarkan teknik Non Random Sampling tersebut maka penulis mempersempit ukuran sampel dengan menggunakan metode purposive sampling dan diperoleh 10 perusahaan sektor Hotel, Restoran, dan Pariwisata dengan periode pengamatan selama 4 tahun dari tahun 2010-2013, maka jumlah sampel yang digunakan berjumlah 40 sampel.

Teknik Pengumpulan Data. Data yang digunakan dalam penelitian ini adalah data sekunder berupa laporan keuangan tahunan (Annual Report). Metode pengumpulan data menggunakan teknik dokumentasi, yaitu dengan melihat dokumen yang sudah terjadi (laporan keuangan dan laporan audit perusahaan).

\section{HASIL DAN PEMBAHASAN}

Berdasarkan uji Kolmogorov Smirnov, maka data mengikuti sebaran normal. Nilai VIF masing-masing variabel bebas $<10$ dan nilai tolerance $>0,10$, sehingga tidak terjadi multikolinearitas. Nilai signifikan Uji Glejser dari semua variabel bebas $>0,05$, sehingga tidak terjadi heteroskedastisitas. Nilai Durbin Watson 2,277 terletak diantara dU $(1,518)$ dan 4-dU (2,482), hal ini berarti asumsi tidak ada autokorelasi.

\section{Analisis Regresi Linier Berganda Dengan Variabel Dummy}

Tabel 2. Hasil Uji Analisis Regresi Linier Berganda Dengan Variabel Dummy

\begin{tabular}{lrr}
\hline & \multicolumn{2}{c}{ Unstandardized Coefficients } \\
\cline { 2 - 3 } Model & \multicolumn{2}{c}{$\mathrm{B}$} \\
\hline (Constant) & 82,295 \\
Ukuran Perusahaan & 1,493 \\
Kompleksitas Operasi & $-1,845$ \\
Perusahaan & $-1,342$ \\
Reputasi KAP & $-13,295$ \\
Opini Auditor & \\
R Square= 0,159 & \\
Regression F = 1,655 & \\
$\quad$ F sig = 0,182 & \\
\hline a.Dependent Variable: Audit Delay
\end{tabular}


Berdasarkan Tabel 2, diperoleh persamaan regresi sebagai berikut:

$$
Y=82,295+1,493 \text { X1 - 1,845 X2 - 1,342 X3 - 13,295 X4 }
$$

Berdasarkan hasil uji koefisien determinasi, diperoleh nilai $\mathrm{R}$ square $\left(\mathrm{R}^{2}\right)$ sebesar 0,159 . Ini berarti variabel audit delay hanya mampu dijelaskan oleh variabel ukuran perusahaan, kompleksitas operasi perusahaan, reputasi KAP, dan opini Auditor sebesar 15,9\% dan sisanya 84,1\% dipengaruhi oleh faktor lain di luar model yang dibangun dalam penelitian ini. Hasil uji F menunjukkan sebesar 1,655 dengan signifikansi sebesar 0,182, disimpulkan bahwa model regresi yang dihasilkan tidak sesuai untuk menguji pengaruh ukuran perusahaan, kompleksitas operasi perusahaan, reputasi KAP, dan opini Auditor terhadap audit delay pada perusahaan Hotel, Restoran, dan Pariwisata yang terdaftar di Bursa Efek Indonesia.

Untuk menguji signifikan atau tidaknya pengaruh ukuran perusahaan, kompleksitas operasi perusahaan, reputasi KAP, dan opini Auditor terhadap audit delay, dilakukan uji t. Berikut di bawah ini menunjukkan hasil pengujian t hitung.

Pengujian pengaruh ukuran perusahaan terhadap audit delay menghasilkan t hitung sebesar 0,282 dengan nilai signifikansi sebesar 0,779. > 0,05, maka diputuskan untuk menerima $\mathrm{H}_{0}$ dan menolak $\mathrm{H}_{1}$, dengan demikian disimpulkan bahwa tidak terdapat pengaruh signifikan ukuran perusahaan terhadap audit delay pada perusahaan Hotel, Restoran, dan Pariwisata yang terdaftar di Bursa Efek Indonesia. Dilihat dari nilai koefisien regresinya sebesar 1,493 , sehingga hipotesis pertama yang menyatakan terdapat pengaruh signifikan ukuran perusahaan terhadap audit delay pada perusahaan Hotel, Restoran, dan Pariwisata yang terdaftar di Bursa Efek Indonesia tidak teruji kebenarannya.

Tabel 3. Hasil Uji t

\begin{tabular}{|c|c|c|c|}
\hline \multirow[b]{2}{*}{ Model } & \multirow{2}{*}{$\begin{array}{c}\begin{array}{c}\text { Unstandardized } \\
\text { Coefficients }\end{array} \\
\text { B }\end{array}$} & \multirow[t]{2}{*}{$\mathrm{t}$} & \multirow[t]{2}{*}{ Sig } \\
\hline & & & \\
\hline $\begin{array}{ll}1 & \text { (Constant) }\end{array}$ & 82,295 & 1,355 & ,184 \\
\hline Ukuran Perusahaan & 1,493 & 282 & 779 \\
\hline Kompleksitas Operasi & $-1,845$ & $-1,383$ & 176 \\
\hline Perusahaan & & & \\
\hline Reputasi KAP & $-1,342$ &,- 158 & 876 \\
\hline Opini Auditor & $-13,295$ & $-1,875$ & 069, \\
\hline
\end{tabular}

\section{a. Dependent Variable: Audit Delay}

Pengujian pengaruh kompleksitas operasi perusahaan terhadap audit delay menghasilkan t hitung sebesar -1,383 dengan nilai signifikansi sebesar 0,176. Karena lebih besar dari 0,05 , maka diputuskan untuk menerima $\mathrm{H}_{0}$ dan menolak $\mathrm{H}_{1}$, dengan demikian disimpulkan bahwa tidak terdapat pengaruh signifikan kompleksitas operasi perusahaan terhadap audit delay pada perusahaan Hotel, Restoran, dan Pariwisata yang terdaftar di Bursa Efek Indonesia. Dilihat dari nilai koefisien regresinya sebesar -1,845, sehingga hipotesis kedua yang menyatakan terdapat pengaruh signifikan kompleksitas operasi perusahaan terhadap audit delay pada perusahaan Hotel, Restoran, dan Pariwisata yang terdaftar di Bursa Efek Indonesia tidak teruji kebenarannya. 
Pengujian pengaruh reputasi KAP terhadap audit delay menghasilkan $\mathrm{t}$ hitung sebesar -0,158 dengan nilai signifikansi sebesar 0,876. Karena lebih besar dari 0,05, maka diputuskan untuk menerima $\mathrm{H}_{0}$ dan menolak $\mathrm{H}_{1}$, dengan demikian disimpulkan bahwa tidak terdapat pengaruh signifikan reputasi KAP terhadap audit delay pada perusahaan Hotel, Restoran, dan Pariwisata yang terdaftar di Bursa Efek Indonesia. Dilihat dari nilai koefisien regresinya sebesar -1,342, sehingga hipotesis ketiga yang menyatakan terdapat pengaruh signifikan reputasi KAP terhadap audit delay pada perusahaan Hotel, Restoran, dan Pariwisata yang terdaftar di Bursa efek Indonesia tidak teruji kebenarannya.

Pengujian pengaruh opini Auditor terhadap audit delay menghasilkan t hitung sebesar -1,875 dengan nilai signifikansi sebesar 0,069. Karena lebih besar dari 0,05, maka diputuskan untuk menolak $\mathrm{H}_{0}$ dan menerima $\mathrm{H}_{1}$, dengan demikian disimpulkan bahwa tidak terdapat pengaruh signifikan Opini Auditor terhadap audit delay pada perusahaan Hotel, Restoran, dan Pariwisata yang terdaftar di Bursa Efek Indonesia. Dilihat dari nilai koefisien regresinya sebesar -13,295, sehingga hipotesis keempat yang menyatakan terdapat pengaruh signifikan opini Auditor terhadap audit delay pada perusahaan Hotel, Restoran, dan Pariwisata yang terdaftar di Bursa Efek Indonesia tidak teruji kebenarannya.

Berdasarkan hasil analisis regresi linier berganda dengan variabel dummy diperoleh bahwa ukuran perusahaan tidak berpengaruh signifikan terhadap audit delay pada perusahaan Hotel, Restoran, dan Pariwisata yang terdaftar di Bursa Efek Indonesia. Hal ini berarti apabila total aset perusahaan Hotel, Restoran, dan Pariwisata yang terdaftar di Bursa Efek Indonesia mengalami peningkatan maupun penurunan, maka audit delay tidak akan mengalami perubahan. Hal ini dikarenakan perusahaan dengan total aset besar maupun kecil mempunyai kemungkinan yang sama dalam menghadapi tekanan atas penyampaian laporan keuangan, tekanan tersebut berasal dari pengawasan pihak investor, badan pengawas pasar modal, dan pemerintah. Oleh karena itu, Auditor akan memeriksa perusahaan dengan total aset besar maupun kecil dengan cara yang sama sesuai dengan prosedur dalam standar profesional akuntan publik.

Berdasarkan hasil analisis regresi linier berganda dengan variabel dummy diperoleh bahwa kompleksitas operasi perusahaan tidak berpengaruh signifikan terhadap audit delay pada perusahaan Hotel, Restoran, dan Pariwisata yang terdaftar di Bursa Efek Indonesia. Hal ini berarti apabila kompleksitas operasi perusahaan Hotel, Restoran, dan Pariwisata yang terdaftar di Bursa Efek Indonesia mengalami peningkatan atau penurunan, maka lamanya waktu penyelesaian audit tidak akan mengalami perubahan secara signifikan. Hal ini dikarenakan perubahan kompleksitas operasi perusahaan sudah pasti diiringi dengan perencanaan perhitungan yang lebih dini. Auditor telah memperhitungkan waktu yang diperlukan dalam perencanaan audit mengenai perubahan kompleksitas operasi suatu perusahaan, sehingga perubahan kompleksitas operasi perusahaan tidak mempengaruhi audit delay.

Berdasarkan hasil analisis regresi linier berganda dengan variabel dummy diperoleh bahwa reputasi KAP tidak berpengaruh signifikan terhadap audit delay pada perusahaan Hotel, Restoran, dan Pariwisata yang terdaftar di Bursa Efek Indonesia. Hal ini berarti tidak terdapat pengaruh antara perusahaan yang menggunakan KAP big four dan non big four terhadap lamanya penyelesaian audit. Tidak adanya pengaruh antara perusahaan yang menggunakan KAP big four dan non big four terhadap audit delay karena baik KAP big four maupun non big four saling berusaha untuk menunjukkan tingkat profesionalisme dalam porses audit, setiap KAP akan berusaha untuk memberikan hasil audit yang terbaik 
agar masyarakat dapat percaya dan senantiasa menggunakan jasa audit yang ditawarkan oleh KAP tersebut.

Berdasarkan hasil analisis regresi linier berganda dengan variabel dummy diperoleh bahwa Opini Auditor tidak berpengaruh signifikan terhadap audit delay pada perusahaan Hotel, Restoran, dan Pariwisata yang terdaftar di Bursa Efek Indonesia. Hal ini berarti perusahaan yang menerima pendapat Unqualified Opinion maupun Unqualified Opinion with explanatory language tidak mempengaruhi audit delay. Hal ini dikarenakan Auditor telah bekerja secara profesional dalam pelaksanaan audit, selain itu auditor telah melakukan prosedur audit dengan baik, sehingga apapun opini yang dikeluarkan auditor baik itu unqualified opinion maupun Unqualified Opinion with explanatory language tidak mempengaruhi lamanya waktu penyelesaian audit.

Berdasarkan hasil Uji F, membuktikan bahwa model regresi yang dihasilkan tidak sesuai untuk menguji pengaruh Ukuran Perusahaan, Kompleksitas Operasi Perusahaan, Reputasi KAP, dan Opini Auditor terhadap audit delay. Hal ini dikarenakan berdasarkan hasil uji koefisien determinasi bahwa variabel audit delay hanya mampu dijelaskan oleh variabel ukuran perusahaan, kompleksitas operasi perusahaan, reputasi KAP, dan opini Auditor sebesar 15,9\% dan sisanya 84,1\% dipengaruhi oleh faktor lain di luar model yang dibangun dalam penelitian ini. Faktor lain yang dimaksud meliputi: variabel profitabilitas, solvabilitas, operasi kerugian dan keuntungan dalam penelitian Kartika (2011), lamanya perusahaan menjadi klien KAP dalam penelitian Prameswari (2012), leverage dan jumlah komite audit dalam penelitian Angruningrum, dkk (2013), jenis industri dalam penelitian Saputri (2012).

\section{PENUTUP}

Simpulan. Model regresi yang dihasilkan dalam penelitian ini tidak sesuai untuk menguji pengaruh Ukuran Perusahaan, Kompleksitas Operasi Perusahaan, Reputasi KAP, dan Opini Auditor terhadap audit delay. Variabel ukuran perusahaan, kompleksitas operasi perusahaan, reputasi KAP, dan opini Auditor tidak berpengaruh signifikan terhadap audit delay pada perusahaan Hotel, Restoran, dan Pariwisata yang terdaftar di Bursa Efek Indonesia.

Implikasi, Keterbatasan Dan Saran. Implikasi Penelitian ini, perusahaan sebagai pihak yang bertugas dalam menyusun laporan keuangan lebih memperhatikan faktor-faktor yang mempengaruhi audit delay, terlebih faktor internal perusahaan karena perusahaan mampu mengendalikan hal yang melingkupi internal perusahaan. Perusahaan juga lebih meningkatkan sistem pengendalian dan selalu berusaha untuk memberikan laporan keuangan yang bebas dari salah saji material, sehingga dapat memberikan informasi yang andal, dan tepat waktu. Informasi yang andal dan tepat waktu tersebut, maka investor, kreditur, masyarakat, dan pemerintah dapat segera melakukan pengambilan keputusan dan menaksir resiko dan keuntungan yang akan terjadi terkait kondisi keuangan perusahaan. Selain itu perlu juga memperhatikan peraturan yang telah dibuat oleh BABEPAM-LK mengenai batas waktu penyampaian laporan keuangan, karena perusahaan yang telah go publik telah menjadi sorotan publik dan patut untuk menyampaikan laporan keuangan tepat waktu.

Bagi perusahaan Hotel, Restoran, dan Pariwisata sebaiknya memperhatikan faktorfaktor yang mempengaruhi audit delay, sehingga perusahaan dapat meminimalisir 
terjadinya audit delay dan berusaha untuk tepat waktu dalam menyampaikan laporan keuangan auditan.

Bagi Auditor dan KAP sebaiknya melaksanakan prosedur audit yang telah dirancang sebelumnya dengan sebaik-baiknya agar lebih meningkatkan efisiensi dan efektifitas dalam menyelesaikan laporan audit secara tepat waktu sesuai dengan waktu yang telah ditentukan oleh BAPEPAM-LK.

Bagi penelitian selanjutnya sebaiknya memperbanyak sampel penelitian dan memperpanjang periode penelitian, serta menambahkan variabel-variabel lain yang dapat mempengaruhi audit delay meliputi variabel profitabilitas, solvabilitas, jenis industri, leverage, laba rugi operasi, lamanya perusahaan menjadi klien KAP, dan Komite audit.

\section{DAFTAR RUJUKAN}

Agoes, Sukrisno, (2012) Auditing Petunjuk Praktis Pemeriksaan Akuntan Oleh Akuntan Publik., Edisi ke Empat., Buku Satu, Penerbit Salemba Empat, Jakarta.

Angruningrum, S. dan Made G.W., (2013) "Pengaruh Profitabilitas, Leverage, Kompleksitas Operasi, Reputasi Kap Dan Komite Audit Pada Audit delay”, E-Jurnal Akuntansi Universitas Udayana 5.2, hal 255, 265

Anis, (2012) "Perusahaan Yang Terlambat Menyampaikan Laporan Keuangan”, http://www.beritasatu.com/ekonomi/65920/laporan-emiten-yang-terlambat, diakses tanggal 04 Januari 2015, 13.43.

Ardiansah, M.S., (2011) "Pengujian Empiris Atas Audit Delay Pada Perusahaan Go Publik Yang Termasuk Dalam JII (Jakarta Islamic Index) Tahun 2005-2009”, Jurnal Sekolah Tinggi Ilmu Ekonomi Perbanas Surabaya, hal 8.

Ariyani, T.D. dan Ketut Budiartha, (2014) "Pengaruh Profitabilitas, Ukuran Perusahaan, Kompleksitas Operasi Perusahaan Dan Reputasi KAP Terhadap Audit Report Lag Pada Perusahaan Manufaktur”, E-Jurnal Akuntansi Universitas Udayana 8.2, hal 224-228.

Arifatun, P.S., (2013) "Pengaruh Ukuran Perusahaan, Profitabilitas Perusahaan, Ukuran Auditor, Dan Opini Audit Terhadap Audit Delay”, Jurnal Profita 2013 75-86, hal 84.

Bursa Efek Indonesia , 2013, "Perusahaan Yang Terlambat Menyampaikan LaporanKeuangan”,http://www.idx.co.id/portals/0/staticdata/newsandannouncement, diakses tanggal 04 Januari 2015, 14.02.

(2015) “Laporan Keuangan Tahunan”, http://www.idx.co.id/idid/beranda/perusahaantercatat/laporan-keuangan-dan-tahunan.aspx, diakses tanggal 19 Januari 2015, 08.52.

(2015) "Laporan Keuangan”, http://www.idx.co.id/idid/beranda/perusahaantercatat/laporan-keuangan-dan-tahunan.aspx, diakses tanggal 3 Maret 2015, 19.37.

(2015) “Profil Perusahaan Tercatat”, http://www.idx.co.id/idid/beranda/perusahaantercatat/profilperusahaantercatat.aspx,diakses tanggal 18 Januari, 17.10.

Butarbutar, Fransisca, (2012) Faktor-Faktor Yang Mempengaruhi Audit Delay Pada Perusahaan Wholesale And Retail Yang Terdaftar Di Bursa Efek Indonesia, Skripsi UPN Veteran Jatim, hal 51

Elder, R.J., M.S. Beasley., A.A. Arens, dan A.A. Jusuf, (2011) Jasa Audit dan Assurance, Buku 2, Adaptasi Indonesia, Penerbit Salemba Empat, Jakarta. 
Erwin, (2012) "Prospek dan Tantangan Ekonomi Indonesia, http://www.slideshare.net/ErwinEAnanto/prospek-dan-tantangan-ekonomi indonesia, diakses tanggal 28 januari 2015, 23.53.

Febrianty, (2011) "Faktor-Faktor Yang Berpengaruh Terhadap Audit delay Perusahaan Sektor Perdagangan Yang Terdaftar Di Bei Periode 2007-2009”, Jurnal Ekonomi dan Informasi Akuntansi (JENIUS), Vol.1, (3), hal 307.

Fuad, (2009) Pengantar Bisnis., Edisi ke Enam, Penerbit Gramedia Pustaka Utama, Jakarta.

Giri, (2012) Akuntansi Keuangan Menengah 1, Penerbit STIE YKPN, Yogyakarta.

Ghozali, I. dan A. Chariri, (2007) Teori Akuntansi., Edisi ke Tiga, Penerbit Universitas Diponegoro, Semarang , (2006) Aplikasi Analisis Multi Variate dengan Progran SPSS., Edisi ke Tiga, Penerbit Universitas Diponegoro, Semarang.

Glover, S.M., William F.M. dan Douglas F., (2005) Auditing \& Assurance Services., Edisi ke Empat., Buku Satu, Penerbit Salemba Empat, Jakarta.

Ikatan Akuntan Indonesia, (2009) Standar Akuntansi Keuangan PSAK No.1, Penerbit Salemba Empat, Jakarta. , (2001) Standar Profesional Akuntan Publik, Penerbit Salemba Empat, Jakarta.

Karyawati, (2013) Akuntansi dan Non-Akuntan, Penerbit Gramedia Pustaka Utama, Jakarta.

Kartika, Andi, (2011) "Faktor-Faktor Yang Mempengaruhi Audit delay Pada Perusahaan Manufaktur Yang Terdaftar Di BEI”, Dinamika Keuangan dan Perbankan Vol 3, (1), hal 164-165.

Kholishah, Siti A.N., (2013) Pengaruh Penerapan Ifrs, Ukuran Perusahaan, Profitabilitas, Dan Kompleksitas Terhadap Audit Delay (Studi Empiris Pada Perusahaan Manufaktur Yang Terdaftar di Bursa Efek Indonesia Pada Tahun 20082011), Skripsi Universitas Islam Negeri Syarif Hidayatullah Jakarta, hal 90-91.

Kusumawardani, Fitria, (2013) "Faktor-Faktor Yang Mempengaruhi Audit delay Pada Perusahaan Manufaktur”, Jurnal Akuntansi, Vol 2, (1), hal 55-57.

Mulyadi, (2010) Auditing, Edisi ke Enam. Cetakan ke Tujuh. Buku Satu, Penerbit Salemba Empat, Jakarta.

Otoritas Jasa Keuangan, (2014) “Statistik Pasar Modal”, Jurnal OJK, hal 3.

Pratama, Baradha, (2014) Analisis Faktor-Faktor yang Mempengaruhi Audit Delaydan Timeliness Pada Perusahaan Publik Di Indonesia, Skripsi Universitas Diponegoro, hal 21.

Pradana, M.N.R. dan Wirakusuma, Md.Gd., (2013) "Pengaruh Faktor-Faktor Nonfinansial Pada Keterlambatan Publikasi Laporan Keuangan Tahunan Perusahaan”, E-Jurnal Akuntansi Universitas Udayana 3.2, hal 291.

Prameswari, Tania, (2012) “Analisis Faktor - Faktor yang Mempengaruhi Terjadinya Audit delay Pada Perusahaan Consumer Good Industry di Bursa Efek Indonesia (Periode Tahun 2008-2010)”, Akurat Jurnal Ilmiah Akuntansi, No. 10, hal 7-12.

Purnamasari, Carmelia, (2012) "Analisis Faktor-Faktor Yang Mempengaruhi Audit delay Pada Perusahaan LQ 45 Yang Terdaftar Di Bursa Efek Indonesia”, Jurnal Universitas Gunadarma, hal 3-8.

Puspitasari, D.K. dan Made, Y.L., (2014) "Pengaruh Ukuran Perusahaan, Anak Perusahaan, Leverage Dan Ukuran Kap Terhadap Audit delay”, E-Jurnal Akuntansi Universitas Udayana 8.2, hal 285-288. 
Puspitasari, E. dan Anggraeni, N.S., (2012) “Pengaruh Karakteristik Perusahaan Terhadap Lamanya Waktu Penyelesaian Audit (Audit Delay) Pada Perusahaan Manufaktur Yang Terdaftar Di Bursa Efek Indonesia”, Jurnal Akuntansi \& Auditing, Vol 9, (1), hal 40-41.

Putra, A.P., (2013) “Kontribusi Pariwisata Terhadap Pertumbuhan Ekonomi Indonesia Meningkat”, http://www.republika.co.id/ berita /gaya hidup/ travelling/13/12/24/mybcdy-kontribusi-pariwisata-terhadappertumbuhan ekonomiindonesia-meningkat, diakses tanggal 3 Maret 2015, 19.57.

Raharjo, (2013) “Teori Sample dan Sampling Penelitian”, http://www. konsistensi.com/2013/04/teorisampeldansamplingpenelitian, diakses tanggal 27 Februari 2015, 07.33.

Ramadhan, Wibisana, (2012) Analisis Faktor-Faktor Yang Mempengaruhi Audit delay (Studi Empiris Pada Perusahaan Manufaktur Yang Terdaftar Di Daftar Efek Syariah Tahun 2008-2010), Skripsi Universitas Negeri Sunan Kalijaga, hal 2.

Saham Ok, (2014) "Sub Sektor Hotel, Restaurant, Pariwisata di BEI", http://www.sahamok.com/emiten/sektor-perdagangan-jasa-investasi/ sub-sektorhotel-restoran-pariwisata, diakses tanggal 29 Januari, 19.23.

Saputri, Oviek, (2012) Analisis Faktor-Faktor Yang Mempengaruhi Audit delay (Studi Empiris Pada Perusahaan-Perusahaan Yang Terdaftar Di Bursa Efek Indonesia), Skripsi Universitas Diponegoro, hal 21-26.

Setiawan, Heru, (2013) Pengaruh Ukuran Perusahaan, Reputasi Auditor, Opini Audit, Profitabilitas, dan Solvabilitas Terhadap Audit Delay (Pada Perusahaan Keuangan Yang Terdaftar Di Bursa Efek Indonesia Periode 2009-2011), Skripsi Universitas Islam Negeri Syarif Hidayatullah Jakarta, hal 90-91.

Subramanyam, (2010) Analisis Laporan Keuangan, Edisi ke Sepuluh. Buku Satu, Penerbit Erlangga, Jakarta.

Sunariyah, (2006) Pengantar Pengetahuan Pasar Modal, Edisi ke Lima, Penerbit Sekolah Tinggi Ilmu Manajemen YKPN, Yogyakarta.

Sutaryo, (2014) "Pengaruh Karakteristik Auditor Terhadap Audit Delay Laporan Keuangan Pemerintah Daerah”, Jurnal Universitas Sebelas Maret, hal 8.

Widosari, Shinta, (2012) "Analisis Faktor-Faktor Yang Berpengaruh Terhadap Audit delay Pada Perusahaan Manufaktur Di Bursa Efek Indonesia Tahun 2008-2010”, Skripsi Universitas Diponegoro, hal 24-27.

Widyasari, Ester, (2011) “Analisis Faktor-Faktor Yang Mempengaruhi Audit Delay Pada Perusahaan Perbankan Yang Terdaftar Di BEI Tahun 2007-2009”, Skripsi Universitas Pembangunan Nasional Veteran Jatim, hal 3.

Yuliyanti, Ani, (2011) "Faktor-Faktor Yang Berpengaruh Terhadap Audit Delay (Studi Empiris Pada Perusahaan Manufaktur Yang Terdaftar Di Bursa Efek Indonesia Pada Tahun 2007-2008)”, Skripsi Universitas Negeri Yogyakarta, hal 95. 


\section{Lampiran:}

\section{Gambar 1: Pertumbuhan Industri Pariwisata}

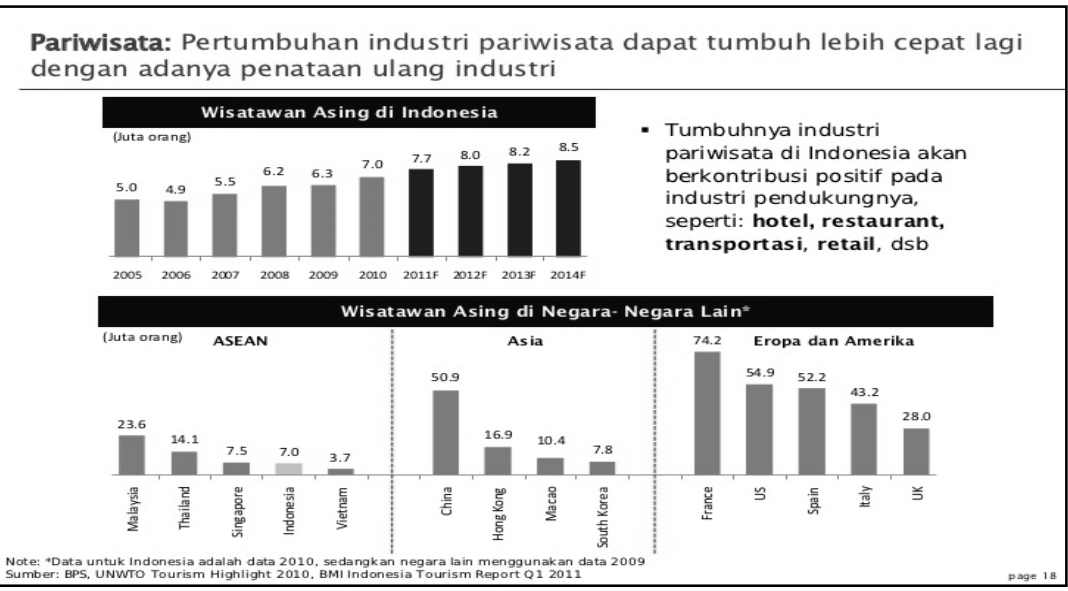

Sumber: Erwin, 2012, "Prospek dan Tantangan Ekonomi Indonesia, http://www.slide share.net?ErwinEananto/prospek-dan-tantangan-ekonomi-indonesia, diakses tanggal 28 Januari 2015, 23.53

Tabel 1: Rata-Rata Audit Delay Perusahaan Sektor Hotel, Restoran, dan Pariwisata Tahun 2010-2013 


\begin{tabular}{|c|c|c|}
\hline Tahun & Jumlah Perusahaan & Rata-Rata Audit Delay \\
\hline 2010 & 18 & 89 hari \\
\hline 2011 & 17 & 88 hari \\
\hline 2012 & 17 & 79 hari \\
\hline 2013 & 17 & 89 hari \\
\hline Sumber: & $\begin{array}{l}\text { Bursa Efek Indonesia, 2015, "Laporan Keuangan", http://www.idx.co.id/id- } \\
\text { Id/beranda/perusahaantercatat/laporankeuangandantahunan.aspx, diakses } \\
\text { Tanggal 3 Maret 2015, 19.37, data diolah }\end{array}$
\end{tabular}

Tabel 2: Hasil Uji Normalitas

\begin{tabular}{|l|r|}
\hline & \multicolumn{2}{|c|}{$\begin{array}{c}\text { Unstandardized } \\
\text { Residual }\end{array}$} \\
\hline Kolmogorov-Smirnov Z & 1,333 \\
Asymp. Sig. (2-tailed) &, 057 \\
\hline
\end{tabular}

a. Test distribution is Normal

b. Calculated From Data

Tabel 3: Hasil Uji Multikolinearitas

\begin{tabular}{|cl|r|r|}
\hline \multirow{2}{*}{ Model } & \multicolumn{2}{|c|}{ Collinearity Statistics } \\
\cline { 3 - 4 } & & Tolearance & VIF \\
\hline 1 & \multicolumn{1}{c|}{ Ukuran } &, 575 & 1,738 \\
& Perusahaan &, 603 & 1,659 \\
& Kompleksitas Operasi & & \\
& Perusahaan &, 744 & 1,345 \\
& Reputasi KAP &, 862 & 1,160 \\
& Opini Auditor & & \\
\hline
\end{tabular}

a. Dependent Variable: Audit Delay

Tabel 4: Hasil Uji Heteroskedastisitas

\begin{tabular}{|cl|r|r|}
\hline Model & \multicolumn{1}{|c|}{$\mathrm{t}$} & \multicolumn{1}{c|}{ Sig } \\
\hline 2 (Constant) & $-1,371$ &, 179 \\
& Ukuran Perusahaan & 1,830 &, 076 \\
& Kompleksitas Operasi & $-1,622$ &, 114 \\
& & \\
& Perusahaan &,- 232 &, 818 \\
& Reputasi KAP &, 140 \\
\hline
\end{tabular}

a. $\quad$ Dependent Variable: RES2

Tabel 5: Hasil Uji Autokorelasi

\begin{tabular}{|l|r|}
\hline \multicolumn{1}{|c|}{ Model } & Durbin Watson \\
\hline 1 & 2,277 \\
\hline \multicolumn{1}{|l}{ b. Dependent Variabel: Audit Delay }
\end{tabular}

